\title{
Evaluation of Biofield Energy Treatment on Physical and Thermal Characteristics of Selenium Powder
}

\author{
Mahendra Kumar Trivedi ${ }^{1}$, Rama Mohan Tallapragada ${ }^{1}$, Alice Branton ${ }^{1}$, Dahryn Trivedi ${ }^{1}$, \\ Gopal Nayak ${ }^{1}$, Omprakash Latiyal ${ }^{2}$, Snehasis Jana ${ }^{2, *}$ \\ ${ }^{1}$ Trivedi Global Inc., Henderson, USA \\ ${ }^{2}$ Trivedi Science Research Laboratory Pvt. Ltd., Bhopal, Madhya Pradesh, India
}

Email address:

publication@trivedisrl.com (S. Jana)

\section{To cite this article:}

Mahendra Kumar Trivedi, Rama Mohan Tallapragada, Alice Branton, Dahryn Trivedi, Gopal Nayak, Omprakash Latiyal, Snehasis Jana. Evaluation of Biofield Energy Treatment on Physical and Thermal Characteristics of Selenium Powder. Journal of Food and Nutrition Sciences. Vol. 3, No. 6, 2015, pp. 223-228. doi: 10.11648/j.jfns.20150306.14

\begin{abstract}
Selenium (Se) is an essential trace element, and its deficiency in the humans leads to increase the risk of various diseases, such as cancer and heart diseases. The objective of this study was to investigate the influence of biofield energy treatment on the physical and thermal properties of the selenium powder. The selenium powder was divided into two parts denoted as control and treated. The Control part was remained as untreated and treated part received Mr. Trivedi's biofield energy treatment. Both control and treated selenium samples were characterized using x-ray diffraction (XRD), differential scanning calorimetry (DSC), thermogravimetric analysis - differential thermal analysis (TGA-DTA), and Fourier transform infrared spectroscopy (FT-IR). The XRD data showed that biofield energy treatment has slightly altered the lattice parameter $(0.07 \%)$, unit cell volume $(0.15 \%)$, density $(-0.14 \%)$, atomic weight $(0.15 \%)$, and nuclear charge per unit volume $(-0.21 \%)$ in the treated selenium powder as compared to the control. The crystallite size of the treated selenium powder was reduced considerably from $106.98 \mathrm{~nm}$ (control) to $47.55 \mathrm{~nm}$. The thermal analysis study showed that the latent heat of fusion was $64.61 \mathrm{~J} / \mathrm{g}$ in the control, which changed to $68.98,52.70,49.71$ and $72.47 \mathrm{~J} / \mathrm{g}$ in the treated T1, T2, T3, and T4 samples respectively. However, the melting temperature did not show any considerable change in the treated selenium samples as compared to the control. The FT-IR spectra showed the absorption peak at 526 and $461 \mathrm{~cm}^{-1}$, which corresponding to metal oxide bonding vibration in the control and treated selenium powder respectively. Hence, overall data suggest that, the biofield energy treatment considerably altered the physical and thermal properties of selenium powder. Therefore, biofield energy treatment could make selenium even more useful nutrient in human body.
\end{abstract}

Keywords: Biofield Energy Treatment, Selenium Powder, X-ray Diffraction,

Thermogravimetric Analysis - Differential Thermal Analysis, Differential Scanning Calorimetry,

Fourier Transform Infrared

\section{Introduction}

The importance of selenium (Se) in human is well established, and its deficiency has caused serious diseases such as cancer and heart disease [1]. Around 25 selenoproteins contain selenium as important element, which are commonly known as selenocysteine [2]. In addition, research on selenium has gained significant attention due to its important role in antioxidant selenoproteins for protection against oxidative stress initiated by excess reactive nitrogen species (RNS) and reactive oxygen species (ROS) [1]. In selenocysteins, selenium metal functions as redox centre in various processes, which includes the reduction of nucleotides in DNA synthesis through selenoenzyme and thioredoxin reductase; and production of active thyroid hormone pre-cursor from selenium-dependent iodothyronine deiodinases [3]. Furthermore, the bioavailability of selenium plays a crucial role in its anticancer and antioxidant activities. It is reported that the particles with crystallite size of nanometre range exhibit better bioavailability and low toxicity as compared to particles with large crystallite size [4-6]. After considering the vast importance of selenium as nutrient in human body, authors wish to investigate an economically safe approach that could be beneficial to 
modify the physical and thermal properties of selenium powder.

It is well established that all atoms are in motion, which contain significant amount of energy. This energy exists in the form of translational, rotation or vibrational, which is evident from vibrational spectroscopy. Similarly, cells of human body consist of various vibratory particles including electron, proton, ions etc. Further, due to vibrations of these particles, electromagnetic radiation emitted and that form an electromagnetic field around the body, known as biofield [7]. Thus, a human has the ability to harness the energy from the environment/universe and can transmit it to any object (living or non-living) around the Globe. The object(s) always receive the energy and responded it into useful way that is called biofield energy. This energy healing process is termed as biofield treatment. The National Center for Complementary and Alternative Medicine (NCCAM) considered this biofield treatment (therapy) in subcategory of energy therapies [8]. Mr. Trivedi's unique biofield energy is also known as The Trivedi Effect ${ }^{\circledR}$. Mr. Trivedi's biofield energy treatment is known to alter the physical, structural and atomic level in various metals [9-11] and ceramics $[12,13]$ in material science. In addition to that, impact of biofield treatment has been significantly studied in the field of microbiology research [14], biotechnology research [15], and agriculture research [16]. Recently, it was reported that biofield treatment had enhanced the crystallite size by two fold in zinc powder [17]. In addition, biofield treatment has significantly altered the crystallite size, unit cell parameter, surface area of magnesium, which is an important micronutrient for human body [18]. Based on the outstanding result achieved with biofield treatment on metals and ceramics, an attempt was made to evaluate the effect of biofield treatment on physical and thermal properties of selenium powder using X-ray diffraction (XRD), Differential Scanning Calorimetry (DSC), Thermogravimetric analysis - differential thermal analysis (TGA-DTA), and Fourier transform infrared spectroscopy (FT-IR).

\section{Materials and Methods}

The selenium powder was purchased from Alpha Aesar, Hyderabad, India. The sample was equally divided into two parts, considered as control and treatment. Control parts remained as untreated, whereas treatment group was in sealed pack and handed over to Mr. Trivedi for biofield treatment under laboratory condition. Mr. Trivedi provided the biofield treatment through his energy transmission process to the treated group without touching. The control and treated samples were characterized using XRD, DSC, TGA-DTA, and FT-IR spectroscopy.

\subsection{X-ray Diffraction Study}

XRD analysis of control and treated selenium powder was carried out on Phillips, Holland PW 1710 X-ray diffractometer system, which had a copper anode with nickel filter. The radiation of wavelength used by the XRD system was $1.54056 \AA$. The data obtained from the XRD system were in the form of a chart of $2 \theta$ vs. intensity and a detailed table containing peak intensity counts, $d$ value $(\AA)$, peak width $\left(\theta^{\circ}\right)$, relative intensity (\%) etc. Additionally, PowderX software was used to calculate the lattice parameter and unit cell volume of selenium powder samples. Total nuclear charge was calculated as the number of protons multiplied by charge on a proton $\left(1.6 \times 10^{-19} \mathrm{C}\right)$. Nuclear charge per unit volume was computed as follow:

$$
\begin{aligned}
& \begin{array}{l}
\text { Nuclear charge per unit volume } \\
\text { Total nuclear charge in an atom }
\end{array} \\
& \text { Volume of an atom }
\end{aligned}
$$

Further, the crystallite size (G) was calculated by using Scherrer formula:

$$
\mathrm{G}=\mathrm{k} \lambda /(\mathrm{b} \operatorname{Cos} \theta),
$$

Here, $\lambda$ is the wavelength of radiation used, $b$ is full width half maximum (FWHM) and $\mathrm{k}$ is the equipment constant (0.94). Furthermore, the percent change in the lattice parameter was calculated using following equation:

$$
\begin{aligned}
& \% \text { change in lattice parameter } \\
& =\frac{\left[\mathrm{A}_{\text {Treated }}-\mathrm{A}_{\text {Control }}\right]}{\mathrm{A}_{\text {Control }}} \times 100
\end{aligned}
$$

Where $\mathrm{A}_{\text {Control }}$ and $\mathrm{A}_{\text {Treated }}$ are the lattice parameter of treated and control samples, respectively. Similarly, the percent change in all other parameters such as unit cell volume, density, atomic weight, nuclear charge per unit volume and crystallite size were calculated.

\subsection{Thermal Analysis}

Thermal analysis of control and treated selenium powder were performed using TGA-DTA and DSC. For DSC analysis, a Pyris-6 Perkin Elmer DSC at a heating rate of $10^{\circ} \mathrm{C} / \mathrm{min}$ under air atmosphere was used. Predetermined amount of sample was kept in an aluminum pan and closed with a lid. A blank aluminum pan was used as a reference. From DSC melting point and latent heat of fusion were recorded. For TGA-DTA analysis, Mettler Toledo simultaneous TGA and Differential thermal analyser (DTA) was used. The samples were heated from room temperature to $400^{\circ} \mathrm{C}$ with a heating rate of $5^{\circ} \mathrm{C} / \mathrm{min}$ under air atmosphere. From TGA curve, percent weight loss was noted. The melting point and latent heat of fusion of control and treated selenium were recorded from DTA curve. The percent change in melting point was computed using following equations:

$$
\% \text { change in meltng point }=\frac{\left[\mathrm{T}_{\text {Treated }}-\mathrm{T}_{\text {control }}\right]}{\mathrm{T}_{\text {control }}}
$$

Where, $\mathrm{T}_{\text {Control }}$ and $\mathrm{T}_{\text {Treated }}$ are the melting point of control and treated samples, respectively. Similarly, the percent change in the latent heat of fusion was computed. 


\subsection{Fourier Transform Infrared Spectroscopy (FT-IR)}

FT-IR spectroscopic analysis was carried out to evaluate the impact of biofield treatment at atomic and molecular level like bond strength, stability, and rigidity of structure etc. FT-IR analysis of control and treated selenium samples were performed on Shimadzu, Fourier transform infrared (FT-IR) spectrometer with frequency range of $300-4000 \mathrm{~cm}^{-1}$.

\section{Results and Discussion}

\subsection{X-ray Diffraction (XRD)}

XRD pattern of control and treated selenium samples are shown in Figure 1a and $1 \mathrm{~b}$ respectively. In XRD pattern of control sample, peaks were observed at $2 \theta$ equal to $23.56^{\circ}$, $29.66^{\circ}, 41.43^{\circ}, 43.65^{\circ}, 45.33^{\circ}, 51.72^{\circ}$, and $56.20^{\circ}$. However,
XRD pattern of treated selenium sample showed peaks at $2 \theta$ equal to $23.43^{\circ}, 23.51^{\circ}, 29.69^{\circ}, 41.30^{\circ}, 43.57^{\circ}, 45.43^{\circ}, 51.73^{\circ}$ and $55.64^{\circ}$. The XRD pattern indicated the hexagonal crystal structure (JCPDS file no. 86-2246) in control and treated selenium samples [18]. In addition, the intense peaks in control and treated sample suggested the crystalline nature of selenium powder. Crystal structure parameters were computed using PowderX software such as lattice parameter, unit cell volume, density, atomic weight, nuclear charge per unit volume. The results are presented in Table 1. Result showed that lattice parameter and volume of unit cell were slightly increased by 0.07 and $0.15 \%$ in treated selenium as compared to control. The increase of unit cell volume may induce internal strain in treated selenium powder. In addition, the atomic weight of treated selenium was slightly increased by $0.15 \%$ as compared to control.
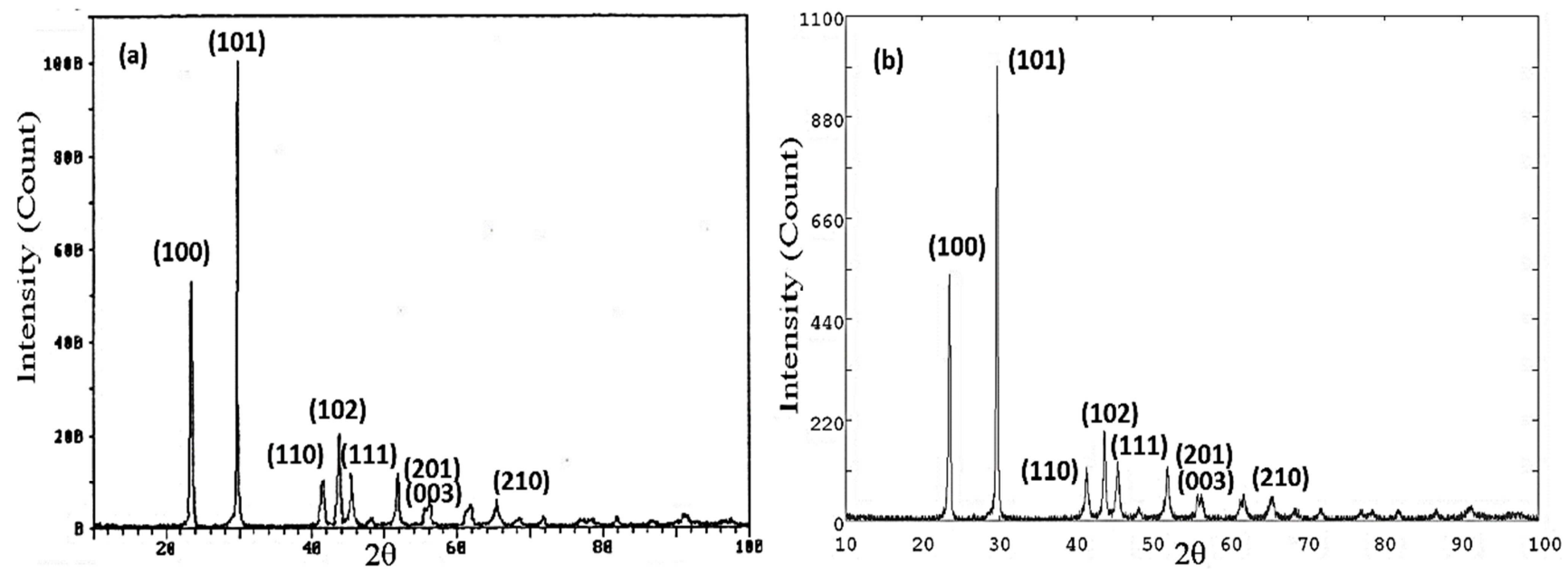

Fig 1. X-ray diffraction pattern of selenium powder (a) control (b) treated.

Table 1. X-ray diffraction analysis of control and treated selenium powder.

\begin{tabular}{llll}
\hline & Control & Treated (T1) & $\begin{array}{l}\text { Percent } \\
\text { change }\end{array}$ \\
\hline Lattice parameter $(\AA)$ & 4.366 & 4.369 & 0.07 \\
Unit cell volume $\left(\times 10^{-23} \mathrm{~cm}^{3}\right)$ & 8.1843 & 8.1962 & 0.15 \\
$\begin{array}{l}\text { Density }(\mathrm{g} / \mathrm{cc}) \\
\text { Atomic weight }(\mathrm{g} / \mathrm{mol})\end{array}$ & 4.849 & 4.842 & -0.14 \\
$\begin{array}{l}\text { Nuclear charge per unit } \\
\text { volume }\left(\mathrm{C} / \mathrm{m}^{3}\right)\end{array}$ & 79.682 & 79.798 & 0.15 \\
Crystallite size $(\mathrm{nm})$ & 124777 & 124511 & -0.21 \\
\hline & 106.98 & 47.55 & -55.55 \\
\hline
\end{tabular}

However, density and nuclear charge per unit volume was decreased by 0.14 and $0.21 \%$, respectively as compared to control. The crystallite size computed using Scherrer formula was found as $106.98 \mathrm{~nm}$ in control and it was reduced to $47.55 \mathrm{~nm}$ in treated selenium powder. It suggests that crystallite size of treated selenium sample was significantly reduced by $55.55 \%$ as compared to control. Fuse et al. reported that the energy produced through mechanical milling had reduced the crystallite size of selenium powder and induced lattice strain in crystal structure [19]. Thus, it is assumed that biofield treatment might induce energy milling in selenium powder and that might be responsible for decrease in crystallite size of treated selenium powder. Recently, our group reported that biofield treatment had reduced the crystallite size in aluminium [20] and magnesium powder [17].

Moreover, selenium is a primary nutrient for human body, thus its bioavailability is an important parameter. It is demonstrated that the rate of dissolution can be altered by choosing a suitable polymorph of a compound i.e. the solids with low crystallinity or high amorphous phase exhibits higher solubility [21]. Torrado et al. reported that solids with small crystallite size exhibits faster dissolution rate as compared to solids with higher crystallite size [22]. Thus, it is hypothesized that biofield treated selenium powder may exhibit the higher dissolution rate, since it has smaller crystallite size as compared to control. The increase in dissolution rate may lead to increase bioavailability of selenium in human gastric fluids.

\subsection{Thermal Analysis}

Thermal analysis of selenium powder was carried out using TGA-DTA and DSC. Thermal analysis results of control and treated selenium powder samples using DSC are 
illustrated in Table 2. DSC showed the melting point of $221.66^{\circ} \mathrm{C}, 222.90^{\circ} \mathrm{C}, 222.16^{\circ} \mathrm{C}$, and $222.12^{\circ} \mathrm{C}$ in control, $\mathrm{T} 1$, $\mathrm{T} 2$ and $\mathrm{T} 3$ respectively. The latent heat of fusion was found as $73.17,73.32,73.11,73.85 \mathrm{~J} / \mathrm{g}$ in control, T1, T2 and T3 respectively. DSC data showed no significant change in melting point and latent heat of fusion in selenium. Furthermore, TGA-DTA analysis results of control and treated selenium samples are presented in Table 3. DTA results showed the melting temperature of $220.92^{\circ} \mathrm{C}$, $220.82^{\circ} \mathrm{C}, 220.50^{\circ} \mathrm{C}, 220.99^{\circ} \mathrm{C}$ and $221.99^{\circ} \mathrm{C}$ in control, $\mathrm{T} 1$, $\mathrm{T} 2$, $\mathrm{T} 3$, and $\mathrm{T} 4$ respectively. It suggests that melting temperature was slightly changed after biofield treatment. Further, TGA data showed the percent weight loss of 7.01, $9.05,3.80,6.81$, and $0.34 \%$ in control, T1, T2, T3, and T4 respectively. Furthermore, DTA integral area was found as $102.66 \mathrm{~s}^{\circ} \mathrm{C}$ in control, which changed to $132.13 \mathrm{~s}^{\circ} \mathrm{C}, 40.38$ $\mathrm{s}^{\circ} \mathrm{C}, 58.08 \mathrm{~s}^{\circ} \mathrm{C}$ and $216.56 \mathrm{~s}^{\circ} \mathrm{C}$ in $\mathrm{T} 1, \mathrm{~T} 2, \mathrm{~T} 3$, and $\mathrm{T} 4$, respectively. These integral area data were further used to calculate the latent heat of fusion of respective control and treated selenium samples. Data showed the latent heat of fusion of $64.61 \mathrm{~J} / \mathrm{g}$ in control selenium powder, which changed to $68.98,52.70,49.71$ and $72.47 \mathrm{~J} / \mathrm{g}$ in T1, T2, T3, and T4 samples, respectively. It indicated that latent heat of fusion was increased by 6.76 and $12.61 \%$ in treated selenium powder $\mathrm{T} 1$ and $\mathrm{T} 4$, whereas it was reduced by 18.43 and $23.07 \%$ in treated $\mathrm{T} 2$ and $\mathrm{T} 3 \mathrm{samples}$ as compared to control.

Table 2. DSC analysis of control and treated selenium powder.

\begin{tabular}{lllll}
\hline Parameters & Control & T1 & T2 & T3 \\
\hline Melting point $\left({ }^{\circ} \mathrm{C}\right)$ & 221.66 & 220.90 & 222.16 & 222.12 \\
Latent heat of fusion $(\mathrm{J} / \mathrm{g})$ & 73.17 & 73.32 & 73.11 & 73.85 \\
\hline
\end{tabular}

$\mathrm{T} 1, \mathrm{~T} 2$, and $\mathrm{T} 3$ are treated samples

Fundamentally, the energy absorbed by any compound during phase change (i.e. solid $\rightarrow$ liquid) is known as latent heat of fusion. During this process, latent heat of fusion is utilized to overcome the inter-atomic interaction in solids to change the phase. In phase change process, latent heat of fusion leads to increase the distance between atoms and stored in atoms as potential energy. Further, the solids with higher interatomic interaction exhibits the higher latent heat of fusion and vice versa. Thus, based on this, it is assumed that biofield treated samples (T1 and T4) probably have higher interatomic interaction as compared to control, which may lead to increase the latent heat of fusion. Contrarily, treated selenium samples T2 and T3 possibly have lower interatomic interaction. It is assumed that the alteration of interatomic interaction in treated selenium powder could be due to change in lattice parameter of unit cell through biofield treatment. It is reported that selenium reacts with various enzymes due to its redox nature i.e. it can oxidise as well as reduce the enzymes [23]. Further, in biological activities, the interatomic interaction of selenium plays a major role. Thus, the reduction of interatomic interaction in selenium powder after biofield treatment may affect the interaction of selenium with enzymes human body.
Table 3. TGA-DTA analysis of control and treated of selenium powder.

\begin{tabular}{|c|c|c|c|c|c|}
\hline Parameters & Control & T1 & T2 & T3 & T4 \\
\hline $\begin{array}{l}\text { SDTA integral area } \\
\left(\mathrm{s}^{\circ} \mathrm{C}\right)\end{array}$ & 102.66 & 132.13 & 40.38 & 58.08 & 216.56 \\
\hline $\begin{array}{l}\text { K-conversion factor } \\
\text { to DSC }\end{array}$ & 5.97 & 5.97 & 5.97 & 5.97 & 5.97 \\
\hline $\begin{array}{l}\text { Melting temperature } \\
\left({ }^{\circ} \mathrm{C}\right)\end{array}$ & 220.92 & 220.82 & 220.50 & 220.99 & 221.99 \\
\hline $\begin{array}{l}\text { Latent heat of } \\
\text { fusion, } \Delta \mathrm{H}(\mathrm{J} / \mathrm{g})\end{array}$ & 64.61 & 68.98 & 52.70 & 49.71 & 72.47 \\
\hline $\begin{array}{l}\text { Percent change in } \\
\Delta \mathrm{H}\end{array}$ & - & 6.76 & -18.43 & -23.07 & 12.16 \\
\hline $\begin{array}{l}\text { Initial mass of } \\
\text { sample (mg) }\end{array}$ & 9.49 & 11.44 & 4.57 & 6.98 & 17.84 \\
\hline $\begin{array}{l}\text { Mass of sample at } \\
\text { melting point (mg) }\end{array}$ & 8.82 & 10.40 & 4.40 & 6.50 & 17.90 \\
\hline Percent weight loss & -7.01 & -9.05 & -3.80 & -6.81 & 0.34 \\
\hline
\end{tabular}

$\mathrm{T} 1, \mathrm{~T} 2, \mathrm{~T} 3$, and T4 are treated samples

\subsection{Fourier Transform Infrared Spectroscopy (FT-IR)}

The FT-IR spectra of control and treated selenium powders are given in Figure $2 \mathrm{a}$ and $2 \mathrm{~b}$, respectively.

In FT-IR spectra, the absorption peaks were observed at 526 $\mathrm{cm}^{-1}$ in control, whereas 461 and $709 \mathrm{~cm}^{-1}$ in treated selenium sample, which can be attributed to metal -oxygen stretching vibration. This peak may be attributed to oxidation of selenium powder [24].

The alteration in absorption peaks could be due to biofield treatment. Furthermore, the absorption peak were observed at $3774 \mathrm{~cm}^{-1}$ in control and $3751 \mathrm{~cm}^{-1}$ in treated selenium powder, which could be due O-H stretching vibrations, which emerged due to moisture absorption by powders. Hence, FT-IR data revealed that biofield treatment has slightly altered the bonding properties of selenium powder.

\section{Conclusion}

The XRD results showed that the crystallite size was reduced by $55.55 \%$ in treated selenium sample as compared to the control, which could be due to the internal strain induced through biofield energy treatment. The reduction in the crystallite size may increase the bioavailability of treated selenium powder in gastric fluid. Thermal analysis indicated that latent heat of fusion was increased by 6.76 and $12.16 \%$ in $\mathrm{T} 1$ and T4, whereas it was reduced by 18.43 and $23.07 \%$ in $\mathrm{T} 2$ and $\mathrm{T} 3$, respectively as compared to the control. Based on the alteration in the latent heat of fusion in treated samples, it is assumed that biofield energy treatment might alter the inter-atomic interaction of the treated selenium powder. The change in interatomic interaction in treated selenium may alter its catalytic activities in human body. Hence, overall study concludes that biofield energy treatment has significantly altered the physical and thermal properties of the selenium powder. Therefore, the biofield energy treated selenium could be more useful as nutrient in human body. 


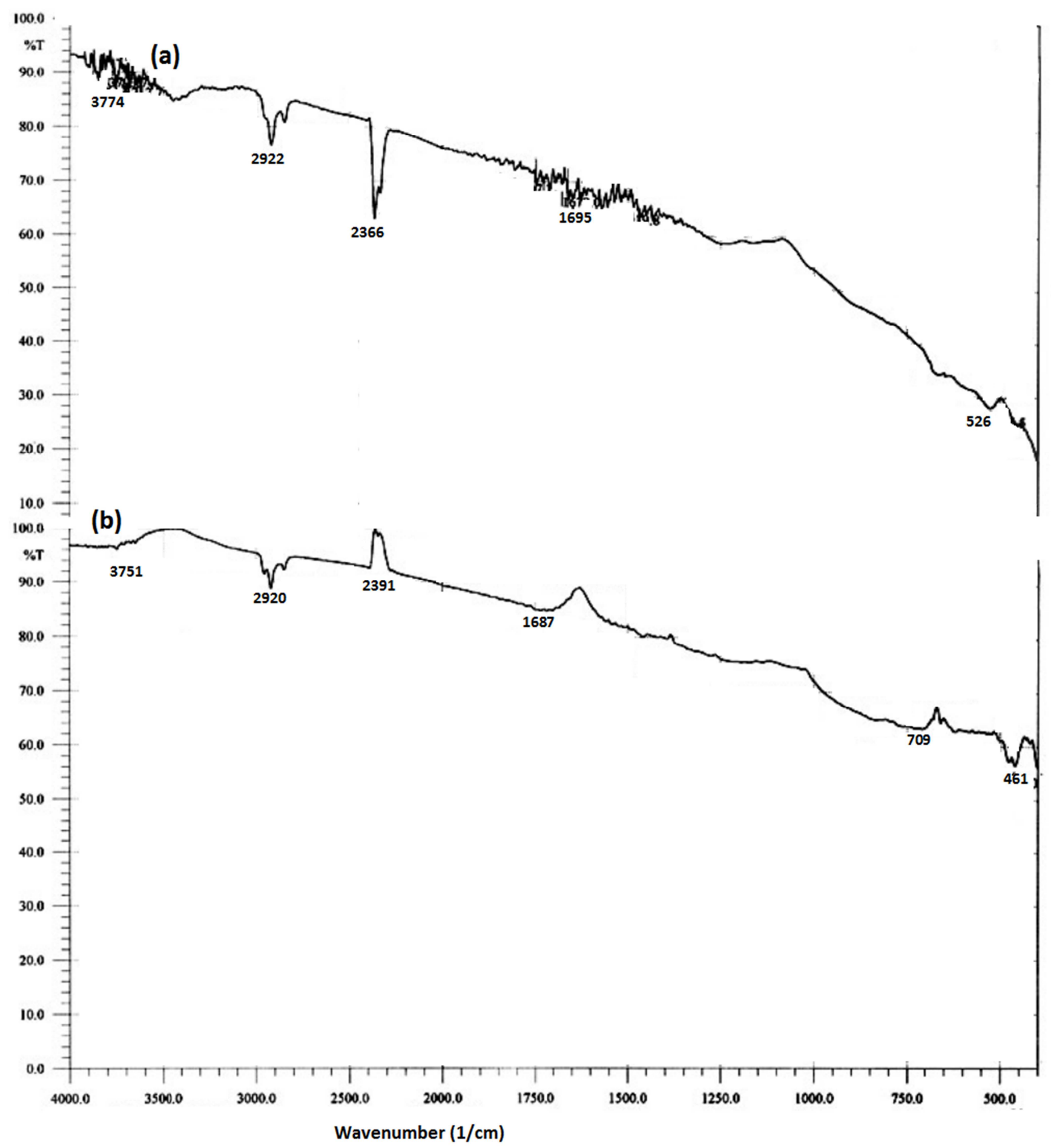

Fig 2. FT-IR Spectra of selenium powder (a) control (b) treated (T1).

\section{Acknowledgment}

Authors gratefully acknowledged to Dr. Cheng Dong of NLSC, Institute of Physics, and Chinese academy of Sciences for providing the facilities to use PowderX software for analyzing XRD data. Authors also would like to thank Trivedi science, Trivedi master wellness and Trivedi testimonials for their support during the work.

\section{References}

[1] Tinggi U (2008) Selenium: Its role as antioxidant in human health. Environ Health Prev Med 13: 102-108.

[2] Gromer S, Eubel JK, Lee BL, Jacob J (2005) Human selenoproteins at a glance. Cell Mol Life Sci 62: 2414-2437. 
[3] Rayman MP (2000) The importance of selenium to human health. Lancet 356: 233-241.

[4] Wang Y, Yan X, Fu L (2013) Effect of selenium nanoparticles with different sizes in primary cultured intestinal epithelial cells of crucian carp, Carassius auratus gibelio. Int J Nanomedicine 8: 4007-4013.

[5] Senthil Kumaran CK, Sugapriya S, Velauthapillai D, Ranjithkumar R, Bellan C (2015) Influence of dietary selenium nanowires on growth performance of broiler chicken. Int $\mathrm{J}$ Biosci Nanosci 2: 78-83.

[6] Wang H, Zhang J, Yu H (2007) Elemental selenium at nano size possesses lower toxicity without compromising the fundamental effect on selenoenzymes: Comparison with selenomethionine in mice. Free Radic Biol Med 42: 1524-1533.

[7] Prakash S, Chowdhury AR, Gupta A (2015) Monitoring the human health by measuring the biofield "aura": An overview. Int J Appl Eng Res 10: 27654-27658.

[8] Hok J, Tishelman C, Ploner A, Forss A, Falkenberg T (2008) Mapping patterns of complementary and alternative medicine use in cancer: an explorative cross-sectional study of individuals with reported positive "exceptional" experiences. BMC Complement Altern Med 8: 48.

[9] Trivedi MK, Patil S, Tallapragada RM (2012) Thought intervention through bio field changing metal powder characteristics experiments on powder characteristics at a PM plant. Future Control and Automation LNEE 173: 247-252.

[10] Trivedi MK, Tallapragada RM (2008) A transcendental to changing metal powder characteristics. Met Powder Rep 63: $22-28,31$.

[11] Trivedi MK, Patil S, Tallapragada RM (2013) Effect of biofield treatment on the physical and thermal characteristics of silicon, tin and lead powders. J Material Sci Eng 2: 125.

[12] Trivedi MK, Patil S, Tallapragada RM (2013) Effect of biofield treatment on the physical and thermal characteristics of vanadium pentoxide powder. J Material Sci Eng S11: 001.

[13] Trivedi MK, Nayak G, Patil S, Tallapragada RM, Latiyal O (2015) Studies of the atomic and crystalline characteristics of ceramic oxide nano powders after bio field treatment. Ind Eng Manage 4: 161.

[14] Trivedi MK, Patil S, Shettigar H, Gangwar M, Jana S (2015) Antimicrobial sensitivity pattern of Pseudomonas fluorescens after biofield treatment. J Infect Dis Ther 3: 222.

[15] Patil SA, Nayak GB, Barve SS, Tembe RP, Khan RR (2012) Impact of biofield treatment on growth and anatomical characteristics of Pogostemon cablin (Benth.). Biotechnology 11: 154-162.

[16] Shinde V, Sances F, Patil S, Spence A (2012) Impact of biofield treatment on growth and yield of lettuce and tomato. Aust J Basic Appl Sci 6: 100-105.

[17] Trivedi MK, Tallapragada RM, Branton A, Trivedi D, Nayak G et al. (2015) Potential impact of biofield treatment on atomic and physical characteristics of magnesium. Vitam Miner 3: 129 (In press).

[18] Razi MK, Maamoury RS, Banihashemi S (2011) Preparation of nano selenium particles by water solution phase method from industrial dust. Int J Nano Dim 1: 261-267.

[19] Fuse M, Shirakawa Y, Shimosaka A, Hidaka J (2003) Mechanically strain-induced modification of selenium powders in the amorphization process. J Nanopart Res 5: 97-102.

[20] Trivedi MK, Patil S, Tallapragada RM (2015) Effect of biofield treatment on the physical and thermal characteristics of aluminium powders. Ind Eng Manage 4: 151.

[21] Raza K, Kumar P, Ratan S, Malik R, Arora S (2014) Polymorphism: The phenomenon affecting the performance of drugs. SOJ Pharm Pharm Sci 1: 10.

[22] Torrado G, Fraile S, Torrado S, Torrado S (1998) Process-induced crystallite size and dissolution changes elucidated by a variety of analytical methods. Int J Pharm 166: 55-63.

[23] Roy G, Sarma BK, Phadnis PP, Mugesh G (2005) Selenium-containing enzymes in mammals: Chemical perspectives. J Chem Sci 117: 287-303.

[24] Santi E, Torre MH, Kremer E, Etcheverry SB, Baran E (1993) Vibrational spectra of the copper(II) and nickel(II) complexes of piroxicam. Vib Spectrosc 5: 285-293. 